\title{
Trust and Purchasing Intention in E-Commerce: Lazada Indonesia
}

\author{
Irda Agustin Kustiwi \\ Department of Accounting \\ Universitas Airlangga \\ Surabaya, Indonesia \\ p.armadiyanti@gmail.com
}

\author{
Isnalita \\ Department of Accounting \\ Universitas Airlangga \\ Surabaya, Indonesia \\ isnalita@feb.unair.ac.id
}

\begin{abstract}
The development of e-commerce has increased quite sharply. Evidenced from customer who likes online transaction than offline payments. Lazada Indonesia as a potential e-commerce company with 21.2 million visitors a month lead, has its own phenomenon to be investigated more deeply. This is related to what variables affect consumers and ecommerce. This study aims to identify the belief in purchasing intention on e-commerce as well as to analyze the relationship between other variables likes perceived risk (PR), perceived ease of use (PEOU), and perceived trusthiworthiness (ability, benevolence, and integrity) to purchasing intention with trust as intermediaries variable in Lazada Indonesia by using Technology Acceptance Model (TAM) as the theoretical basis. Quantitative methods are used in this paper. The total sample is 120 respondents with the purposive sampling method is used and conducted by spreading questionnaires through online information media by Google. Data collectin is measured on five point likert type scale and used WrapPLS version 6.0 software to analyze structural equations model-partial least squares (SEMPLS). The finding of this research indicates that perceived ease of use (PEOU), Ability, Benevolence, and Integrity have significant positively influence relationship to trust. It is different with perceived risk (PR) is rejected because there are policies to protect consumers. Overall trust also has a significant positively influence relationship to purchasing intentions. This study suggests that can add more variants of variables related to consumer behavior, especially on purchasing intention in ecommerce. Then, the retailers can develop consumer positively with customer satisfaction through increasing trust that directly affect to purchasing intention in e-commerce as one of the media business transactions in the future.
\end{abstract}

Keywords-e-commerce; purchasing intention; Lazada; technology acceptance model; trust

\section{INTRODUCTION}

Electronic commerce or commonly known as e-commerce, is a component from the development of information technology systems with organizations that related in business and trades digitalization where its usefulness can be felt directly by many parties such as business to business (B2B), business to consumer (B2C), and consumer to customer (C2C). It is potential that makes e-commerce to be adopted by all countries (both developed and developing countries). E- commerce was first applied around 1996 in Indonesia. Although the early adoption of this system was slowly received, it has now had a significant impact on Indonesia's economic sector. Badan Koordinasi Penanaman Modal (BKPM) revealed that the investment value generated through this model exceeds US $\$ 5$ billion by 2017, which indicates that e-commerce has experienced rapid growth [1].

Lazada Indonesia is one of companies that used ecommerce model in retail online by offering various products and needs from infants to adults. The company is part of the Lazada Group which has expanded in Southeast Asia and was established in March 2012 in Indonesia. According to a survey institute conducted by IlmuOneData [2], Lazada Indonesia ranked first in terms of top performing online consumer goods with $21.35 \%$ and top consumer goods ecommerce with changes increased with $60 \%$ by unique visitors January until June 2017 or equivalent 21,2 million visitors per month . From this data research can identify that Lazada has different challenges and opportunities from other countries in due to adopting a marketing channel by using e-commerce on its business. The differences are both from demographic factors, regulations, laws, to consumer behavior towards purchasing decisions online.

Relating with purchasing intentions, trust has a major role in decisions to buy especially online transactions. This explaination supported by [3-8]. Trust can be used as the main variable or intermediary other variant variables that related to purchasing intention. In addition, technology information usage behavior factors also affect the purchasing intention indirectly. Based on the description, in this study will focus on identifying and explaining the influence of the relationship other variables that related purchasing intention in online transactions with trust as an intermediary variable in Lazada Indonesia by using Technology Acceptance Model (TAM) as theoretical basis. This research provide valuable insight both scientifically and contextually about consumer behavior to purchasing intentions in e-commerce. 


\section{LITERATURE REVIEW}

\section{A. Technology Acceptance Model (TAM)}

In management information system subjects, there are several theories used to determine the factors acceptance of technology used by information users. There are Theory of Reasoned Action (TRA), Theory of Planned Behavior (TPB), and Technology Acceptance Model (TAM).

TAM was first introduced by Davis in 1986. [10] explained that TAM uses TRA as a basic theory relating to consumer attitudes and behavior. But TAM's specific objectives are used to measure attitudes and behavior of information technology users (usage behavior) using two major variables on perceived usefulness and perceived ease of use. So it can be used both by researchers and practitioners in knowing the external factors that can affect and perform accurate steps.

The development of TAM methods can be used to explain e-commerce issues according to the main subject of this research. This model is used as an important component for knowing and finding relationship between internet usage factor likes attitude, trust, and behaviour intention (especially in e-commerce). Other variables that related with user acceptance in online transactions are perceived risk, perceived ease of use, and perceived of trusthiworthiness to purchasing intenstion trust as moderating variable.

\section{B. Perceived Risk (PR)}

Risk is one factor considered by consumers who take decision making buy in digital transactions. One example of performance risk is the incompatibility of product and service functions expected by consumers [9]. Furthermore, performance risk is part of perceived risk which creates uncertainty in e-commerce transactions. Another opinion about perceived risk is measured through the assessment of each individual by looking with wide dimension in ecommerce such as comprehensive services and products.

This opinion is also consistent with research [3], [10], [11] that represented uncertainty perceived risk risk is one of the constraints factor in relationship between trust and behaviour intention especially in digital transactions. Based on the above explanation, the first hypothesis of this study as follows:

\section{H1. PR has a negative significant effect on trust.}

\section{Perceived Ease of Use (PEOU)}

The internet has revolutionized make consumers prefers digital transactions than conventional. It is because of the numerous benefits likes more variety, cheaper, and less time. [6] describes PEOU are individual beliefs about the use of technology that does not require more effort in its use, it means simple to use. This proves that PEOU is a part of acceptance model and affect on purchasing decisions. Another research in China about PEOU, describe that PEOU have a significant role for consumer to decide purchase in online [3]. Ease of use is key factor when consumers want from a product or service. With high trust and ease of use, consumers will be make purchasing decisions if the vendor have fast access server, simple process, and payments. Based on above explanation, the second hypothesis of this study as follows:

\section{H2: PEOU has a positive significant effect on trust.}

\section{Perceived Trusthiworthiness}

Perceived trustworthinesss is a subject that related with trust and has a significant role in digitalization business, either directly related with behavior intention. Which not only affects on purchasing intention in digital transaction, but also related to suppliers, retailers, and others. Trust consists of three dimensions including ability, benevolence, and integrity [5], [7], [12].

\section{E. Ability}

Ability is not only more focus on consumers behavior and competency, but also in organizations that are adjusted to a specific character. According to [5], ability is one dimension of perceived trusthiworthiness that has a direct effect on consumer behavior in making purchasing decisions. Based on the above explanation, the third hypothesis of this study as follows:

\section{H3: Ability has a positive significant effect on trust.}

\section{F. Benevolence}

Benevolence is second dimensions of perceived trusthiworthiness. It is all about consumer behavioural or organizations that focus in business operational. For the example, communicating about specification good, terms, and other between seller-customer. Benevolence has a direct effect on trust [5]. Based on the above explanation, the fourth hypothesis of this study is as follows:

\section{H4: Benevolence has a positive significant effect on trust.}

\section{G. Integrity}

The last dimension of perceived trusthiworthiness is integrity. It is related about personal character. The concept of integrity means doing right things in accordance with value, principle, expectations in reliable ways. This statements is supported by [5], integrity has effect on consumer behavior especially trust. Based on the above explanation, the fifth hypothesis of this study as follows:

\section{H5: Integrity has a positive significant effect on trust.}

\section{H. Trust}

Initially trust is one of main subject in psychology. However it is use in a social and economic context. When it comes related with consumer and technology, trust is a matter of dispute. As explained [13], trust is a benchmark in business transactions achieved through customer satisfaction.

There are many literatures and definitions about trust, but it is more specifically base for business implementation that relates to the beliefs of both partners to proof and fulfillment of all responsibilities for transactions in accordance with expectations and creation of customer satisfaction.

The importance of trust factors in e-commerce is also supported by research [3], [4], [5], [6], [7], [8]. Consumers can able to buy some products and services online when they have confindence and trust in e-commerce. The indicators used in belief factor can be determined through comfort, satisfaction, 
and responsibility. Off course, it is directly influence in purchasing intention. Based on the above explanation, thelast hypothesis this study as follows:

H6: Trust has a positive significant effect on purchasing intention.

\section{RESEARCH METHOD}

The type of this paper used quantitative research with designs and techniques explanatory approach. Analyzing the influence of relationships between variables to identify the hypothesis and describe the phenomenon between PR, PEOU, ability, benevolence, and integrity to trust. Besides that, the impact of trust on purchasing intention in e-commerce on Lazada, Indonesia. [14] explains that the definition of explanatory approach which is one of the studies based on hypotheses that are useful to test the events that occur. The subjects used online marketplace users in Indonesia who have made purchases transactions both products or services provided through Lazada without any limit on the number of transactions purchased.

The total sample is 120 respondents obtained through the spread of questionnaires with the Google online form media conducted during November and December 2017. There are 33 items of questions consist of 3 items of PR questions [ 3 items [10],[11]; 7 item questions PEOU [3], [6]; 4 item questions Ability [7], [12]; 3 items Benevolence [7], [12]; 3 items Integrity [7], [12]; 3 Trust items [12], [15], and 10 items PI [8].

Data collection is measured by five point likert type scale where the lowest Strongly Disagree $=1$ to the highest Strongly Agree $(\mathrm{SS})=5$. The method technique used is purposive sampling and analyzed by WrapPLS version 6.0 software to describe SEM-PLS. The reasons is, WrapPLS can calculate and explain relationship between independent variables to dependent variables. It also can indicate latent variables with indicators to be used in this research.

\section{RESUlts AND DisCUSSION}

\section{A. Respondents Description}

A survey was conducted on consumers who have made transactions with a total sample is 120 respondents. They have diverse many characters in terms of gender, age, education, and profession that presented in any several categories in Table 1 to identify our research model.

TABLE I. SAMPLE CHARACTERISTICS $(\mathrm{N}=120)$

\begin{tabular}{|c|c|c|c|}
\hline \multirow{3}{*}{ Measure } & Items & Frequency & Percent \\
\hline \multirow{3}{*}{ Age } & Male & 49 & $40.83 \%$ \\
\cline { 2 - 4 } & Female & 71 & $59.17 \%$ \\
\cline { 2 - 4 } & $<20$ & 2 & $1.67 \%$ \\
\cline { 2 - 4 } & $20-29$ & 69 & $57.50 \%$ \\
\cline { 2 - 4 } & $30-39$ & 30 & $25 \%$ \\
\hline
\end{tabular}

\begin{tabular}{|c|c|c|c|} 
& $>50$ & 7 & $5.83 \%$ \\
\hline \multirow{4}{*}{ Education } & $\begin{array}{c}\text { Junior/ Senior High } \\
\text { School }\end{array}$ & 2 & $1.67 \%$ \\
\cline { 2 - 4 } & Bachelor & 108 & $9 \%$ \\
\cline { 2 - 4 } & Master & 10 & $8.33 \%$ \\
\cline { 2 - 4 } & Doctor & - & - \\
\hline \multirow{3}{*}{ Profession } & Employee & 95 & $79.17 \%$ \\
\cline { 2 - 4 } & Student & 24 & $20 \%$ \\
\cline { 2 - 4 } & Housewife & 1 & $0.83 \%$ \\
\hline
\end{tabular}

Table 1 describes the majority of consumers are women who have a percentage of $59.17 \%$, aged $20-29$ years of $57.50 \%$ with education background $9 \%$ bachelor and have profession as employee $79.17 \%$. This is contribute with the Lazada innovation which combines its activities through social media, so the target is usually more consumptive customers. There are women with age 20-29 years who have bachelor background education and have worked, then purchasing intention and customer satisfaction can be improved.

\section{B. Analysis of SEM-PLS}

\section{1) Outer Model (Model Measurement)}

The Analysis of SEM-PLS consists of two research models, there are measurement model and structural model. The measurement model is a method used to measure relationship between indicators tested with latent variables. This model is performed before a structural model, consisting of a test of reliability, a convergence validity test, and a discriminant validity test [16] which will be showed in Table 2.

TABLE II. CONVERgENANT VALIDITY AND RELIABILITY TEST

\begin{tabular}{|c|c|c|c|c|c|}
\hline Constructs & Items & $\begin{array}{c}\text { Outer } \\
\text { Loadings }\end{array}$ & AVE & $\begin{array}{l}\text { Composite } \\
\text { Reliability }\end{array}$ & $\begin{array}{c}\text { Cronbach's } \\
\text { alpha }\end{array}$ \\
\hline \multirow{2}{*}{ PR } & PR1 & 0.907 & \multirow{2}{*}{0.823} & \multirow{2}{*}{0.903} & \multirow{2}{*}{0.785} \\
\hline & PR2 & 0.907 & & & \\
\hline \multirow{5}{*}{ PEOU } & PEOU1 & 0.820 & \multirow{5}{*}{0.673} & \multirow{5}{*}{0.911} & \multirow{5}{*}{0.878} \\
\hline & PEOU3 & 0.870 & & & \\
\hline & PEOU4 & 0.841 & & & \\
\hline & PEOU5 & 0.768 & & & \\
\hline & PEO7 & 0.800 & & & \\
\hline Ability & A1 & 1.000 & 1.000 & 1.000 & 1.000 \\
\hline \multirow{2}{*}{ BNVLNC } & B1 & 0.868 & \multirow{2}{*}{0.754} & \multirow{2}{*}{0.860} & \multirow{2}{*}{0.674} \\
\hline & B3 & 0.868 & & & \\
\hline \multirow{3}{*}{ INTGRTY } & I1 & 0.858 & \multirow{3}{*}{0.612} & \multirow{3}{*}{0.825} & \multirow{3}{*}{0.679} \\
\hline & I2 & 0.728 & & & \\
\hline & I3 & 0.754 & & & \\
\hline \multirow{2}{*}{ Trust } & $\mathrm{T} 1$ & 0.919 & \multirow{2}{*}{0.844} & \multirow{2}{*}{0.916} & \multirow{2}{*}{0.816} \\
\hline & $\mathrm{T} 2$ & 0.919 & & & \\
\hline
\end{tabular}




\begin{tabular}{|l|c|c|c|c|c|}
\multirow{3}{*}{ PI } & PI2 & 0.816 & \multirow{4}{*}{0} & \\
\cline { 2 - 3 } & PI9 & 0.851 & 0.663 & 0.855 & 0.745 \\
\cline { 2 - 3 } & PI10 & 0.774 & & & \\
\hline
\end{tabular}

TABLE III. DISCRIMINANT VALIDITY TEST

\begin{tabular}{|c|c|c|c|c|c|c|c|}
\hline & PR & PEOU & A & B & I & $\mathbf{T}$ & PI \\
\hline PR1 & 0.907 & -0.123 & 0.073 & 0.081 & -0.15 & 0.085 & -0.02 \\
\hline PR2 & 0.907 & 0.123 & $0 . \overline{073}$ & -0.08 & 0.152 & -0.09 & 0.016 \\
\hline PEOU1 & $\stackrel{-}{0.011}$ & 0.820 & 0.035 & 0.235 & -0.35 & 0.295 & -0.21 \\
\hline PEOU3 & $\begin{array}{c}- \\
0.103 \\
\end{array}$ & 0.870 & $\begin{array}{c}- \\
0.083 \\
\end{array}$ & 0.356 & -0.33 & 0.094 & 0.148 \\
\hline PEOU4 & 0.184 & 0.841 & 0.103 & -0.39 & 0.387 & -0.1 & -0.11 \\
\hline PEOU5 & $\begin{array}{c}- \\
0.072\end{array}$ & 0.768 & 0.093 & -0.7 & 0.832 & -0.37 & 0.012 \\
\hline PEOU7 & $\begin{array}{c}- \\
0.001\end{array}$ & 0.800 & $\begin{array}{c}- \\
0.143\end{array}$ & 0.451 & -0.49 & 0.057 & 0.157 \\
\hline A1 & 0.000 & 0.000 & 1.000 & 0.000 & 0.000 & 0.000 & 0.000 \\
\hline B1 & 0.084 & -0.032 & $\begin{array}{c}- \\
0.152 \\
\end{array}$ & 0.868 & 0.453 & 0.082 & 0.044 \\
\hline B3 & $\begin{array}{c}- \\
0.084 \\
\end{array}$ & 0.032 & 0.152 & 0.868 & -0.45 & -0.08 & -0.04 \\
\hline I1 & 0.045 & -0.029 & -0.17 & 0.325 & 0.858 & 0.086 & 0.071 \\
\hline I2 & 0.078 & -0.003 & 0.062 & -1.61 & 0.728 & -0.02 & -0.07 \\
\hline I3 & 0.127 & 0.036 & 0.134 & 1.187 & 0.754 & -0.08 & -0.02 \\
\hline T1 & $\begin{array}{c}- \\
0.043\end{array}$ & 0.017 & $\begin{array}{c}- \\
0.005\end{array}$ & -0.24 & 0.24 & 0.919 & 0.087 \\
\hline $\mathrm{T} 2$ & 0.043 & -0.017 & 0.005 & 0.24 & -0.24 & 0.919 & -0.09 \\
\hline PI2 & 0.109 & 0.088 & 0.106 & -0.15 & 0.051 & -0.07 & 0.816 \\
\hline PI9 & 0.021 & 0.15 & 0.042 & 0.223 & -0.24 & -0 & 0.851 \\
\hline PI10 & $\begin{array}{c}- \\
0.137\end{array}$ & -0.258 & $\begin{array}{c}- \\
0.159\end{array}$ & -0.09 & 0.214 & 0.077 & 0.774 \\
\hline
\end{tabular}

Table 2 and 3 explains reliability and validity testing using wrapPLS version 6.0 software that must accordingly the requirements with score values at outer loading presented> 0.70 [17], AVE value $>0.50$, reliability test value $>0.70$, and cronbach's alpha> 0.60 [18] .

The results reveal that PR3 is a part of Perceived Risk (PE), PEOU2 and PEOU6 which are part of Perceived Ease Of Use (PEOU), A2 and A3 which are part of Ability, B2 which is part of Benevolence (BNVLNC), and PI1, PI3, PI4, PI5, PI6, PI7, and PI8 which are part of the Purchasing Intention (PI) have been excluded from data processing because they do not fit the requirements of outer loadings that should be $>0.70$. In addition, in Table 2 and 3 can be concluded that this study is valid and reliable because it fits with requirements of AVE, composite reliability, and cronbach's alpha values. Intention and customer satisfaction can be improved.

\section{2) Inner Model (Structural Model)}

The structural model is the final evaluation method that is test after the measurement model using PLS software. It explains relationship between construct (exogenous or endogenous). This evaluation method is measured through linear regression
(R2) and the path coefficient estimation which will be described below in Figure 1.

FIGURE 1. PLS-SEM MODEL

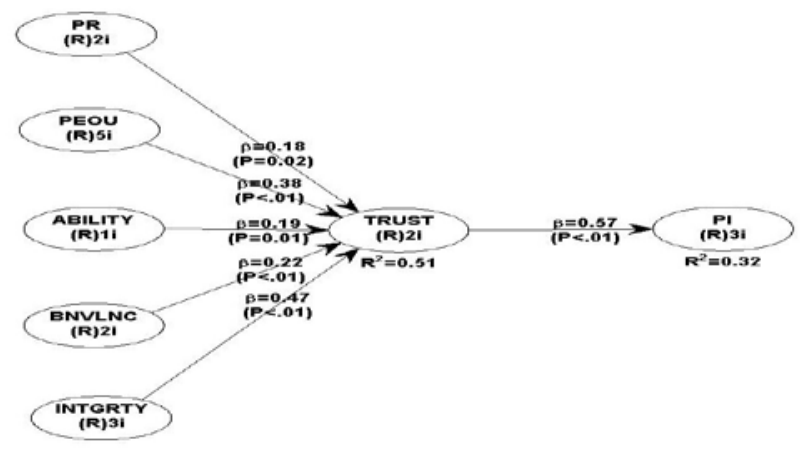

Fig. 1. PLS-SEM Model

Figure 1 shows, PR has no effect on trust with coefficient value of 0.18 and $p$ value equals 0.02 . Therefore hypothesis 1 is rejected. According to explanation [3], risk is closely related about performance mismatch of goods and its specifications. Moreover, there are many tipe of risks likes damage, fake, and unexpected goods. However, this can be minimized with Lazada's policy to protect consumers with returns. Besides, Indonesia has legal system about electronic transactions. It is the electronic information and transactions (EIT) Law, No. 11 of 2008 [19]. The results of this study do not support previous statements [3], [10], [11].

PEOU has a positive significant effect on trust. Proven from $\beta=0.38$ and $p<0.01$. PEOU is important component for customer to increase trust. Usability will lead to increase consumer confidence and improve sales. This finding has direct link between PEOU and trust is supported by research [3], [6].

Ability has a positive significant effect on trust with coefficient value $=0.19$ and $\mathrm{p}$ score $=0.01$. Ability is first dimensions of perceived trusthuworthiness that contains of competency, experience, knowledgement, and institutional knowledgement. It can produce a given result and well services. The results is same with previous studies [7] and [12].

Benevolence has a positive significant effect to trus with $\beta$ $=0.22$ and $\mathrm{p}<0.01$. In economic context, there is correlation between benevolence and trust. It can be seen from optimism customers to have attention, sharing, and expectation. This result has supported by [7] and [12].

Trust has a positive significant effect to purchasing intentions. The results can be seen from the value of $R^{2}=0.51$. Trust is an important factor for increasing purchasing intentions in ecommerce. Which can measure from customer participation to recommended other people and become customer loyalty. This study describes that are not different from [12], [15], [20] which explain trust that have a significant effect on customer purchase intentions. 


\section{CONCLUSION AND LIMITATIONS}

Based on the results about purchasing intentions in ecommerce Lazada Indonesia, it can indicates that PEOU, Ability, Benevolence, and Integrity have significant positively influence relationship to trust. Unlike PR is rejected because there are policies to protect consumers. This indicates that consumers already know and understand the online purchasing requirements of Lazada Indonesia. As a top brand, Lazada also provide the best service with the returns if the occurrence of risks such as damaged, fake, or lost products. In general, it can be concluded that Trust have significant positively influence relationship to purchasing intentions in e-commerce. It has potential benefits and risks are significant enough to require trust as the main factor in conducting transactions online.

Our study has limitations which have not pointed out other variables related to e-commerce purchasing intentions such as reputation, service, quality, and others. By adding more variable variance is expected to provide new insight on customer behavior. In addition, although the sample has accordingly with requirements of SEM, it can expand the time period in the study to be performed. It is expected to obtain more accurate and relevance findings.

\section{REFERENCES}

[1] A. Librianty, "5 Prediksi Tren e-Commerce di Indonesia pada 2018 Liputan6.com,” Liputan6.com, 2018. [Online]. Available: https://www.liputan6.com/tekno/read/3230715/5-prediksi-tren-ecommerce-di-indonesia-pada-2018. [Accessed: Apr. 16, 2018].

[2] Y. Nathania, “2017, Pertumbuhan E-Commerce Indonesia Meningkat Tajam, Siapa di Posisi Teratas?” business.idntimes.com, 2017. [Online]. Available: https://business.idntimes.com/economy/yoshi/pertumbuhane-commerce-indonesia-1/full. [Accessed: Apr. 16, 2018].

[3] R. Li, J. J. Kim, J.S. Park, “The Effects of Intenet Shoppers' Trust on Their Purchasing Intention in China,” J. of Inform. Syst. and Technol. Manage., vol. 4, no. 3, pp. 269-286, 2007.

[4] B. J. Corbit, T. Thanasankit, and H. Yi, "Trust and E-commerce: a Study of Consumer Perceptions,” Electr. Comm. Res. and Appli., vol. 2, pp. 203-215, 2003.

[5] J. O. B. Rotimi, R. Lambers, and F. Zaeri, “Trust and Interorganizational Interactions for Managing Conflicts in a Blended Team,” J. of Leg. Aff. and Disp. Resol. in Eng. and Constr., vol. 8, no. 1, February 2016.
[6] F. D. Davis, "Perceived Usefulness, Perceived Ease Of Use And User Acceptance Of Information Technology,” MIS Quart., vol. 13, no. 3, pp. 318-39, 1986.

[7] P. Pavlou and D. Gefen, "Building Effective Online Marketplaces with Institution-based Trust," Proceedings of Twenty-Third International Conference on Information Systems, pp. 667-675, 2002.

[8] Kotler, Philip and K. L. Keller, Marketing Management. 13rd ed. New Jersey: Pearson Prentice Hall, 2009.

[9] C. M. Chiu, E. T. G. Wang, Y. H. Fang, and H. Y. Huang, "Understanding Customers Repeat Purchase Intentions in B2C Ecommerce: The Roles of Utilitarian Value, Hedonic Value and Perceived Risk,” Inform. Sys. J., vol. 24, pp. 85-114, 2012

[10] J. P. Peter and L. X. Tarpey, "A Comprehensive Analysis of Three Consumer Decision Strategies,” J. of Cons. Res., vol. 2, pp. 29-37, 1975.

[11] B. Dai, S. Forsythe, and W. S. Kwon, "The Impact of Online Shopping Experience on Risk Perceptions and Online Purchase Intentions: Does Produk Category Matter?” J. of Elect. Comm. Res., vol. 15, no. 1, 2014.

[12] E. Kim and S. Tadisina, "Customer's Initial Trust in E-Business: How to Measure Customer's Initial Trust,” Proceedings of Ninth Americas Conference on Information Systems, pp. 35-41, 2003.

[13] S. Y. Yousafzai, J. G. Pallister, and G.R. Foxall, “A Proposed Model of E-Trust for Electronic Banking,” Technov. J., vol. 23, no. 11, November, pp. 847-860, 2003.

[14] D. R. Cooper and P. S. Schindle, Metode Riset Bisnis [Business Research Methods]. Jakarta: PT. Media Global, 2006.

[15] H. W. Kim \& Y. Xu, "Internet Shopping: Is It a Matter of Perceived Price or Trust?” Proceedings of Twenty-Fifth International Conference on Information Systems, pp. 831-842. 2004.

[16] W. W. Chin, “The Partial Least Square Approach to Structural Equation Modeling, in G.A. Marcoulides (Ed),” Modern Methods For Business Research. London and New Jersery: Lawrence Erlbaum Associates, Mahwah, 1998, pp. 295-336.

[17] M. Sholihin and D. Ratmono, Analisis SEM-PLS dengan WarpPLS 3.0 untuk Hubungan Nonlinier dalam Penelitian Sosial dan Bisnis [Analysis of SEM-PLS with WarpPLS 3.0 for Non-linear Relationship in Social and Business Research]. Yogyakarta: Penerbit Andi, 2013.

[18] Solimun, A. A. Fernandes, and Nurjannah, Metode Statistika Multivariat Pemodelan Persamaan Struktural (SEM) Pendekatan WarpPLS [Multivariate Statistics Method of Structural Equation Modeling (SEM) with WarpPLS Approach]. Malang: UB Press, 2017.

[19] K. Molina, "Indonesian Electronic Information and Transactions Law Amended,” - Whitecase.com, 2016. [Online]. Available: https://www.whitecase.com/publications/alert/indonesian-electronicinformation-and-transactions-law-amended. [Accessed: Apr. 10, 2018].

[20] L. Tung, P. Tan, P. Chia, Y. Koh, and H. L. Yeo, "An Empirical Investigation of Virtual Communities and Trust," Proceedings of Twenty-Second International Conference on Information Systems, pp. 307-319, 2001. 